\title{
The inhibition effects of methionine on mild steel in acidic media
}

\author{
Albana JANO*, Alketa LAME (GALO) and Efrosini KOKALARI (TELI)
}

Natural Sciences Faculty, Chemistry Department, Tirana University, Bulevardi Zogu i Parë, Tirana, Albania

\begin{abstract}
The corrosion of metal surfaces causes huge financial damages to the industries annually, what has lead to an increase in the search for substances that can slow down or prevent corrosion rate. Green inhibitors which are biodegradable, without any heavy metals and other toxic compounds, are promoted. Amino acids are attractive as corrosion inhibitors because they are nontoxic. We have used methionine as corrosion inhibitor. Materials under investigation are two kind of low allow carbon steel marked as: Steel 39, Steel 44 usually applied to concrete as reinforcing bars, and manufacture in Elbasan. The inhibition effect of methionine on the corrosion behavior of low allow steel is investigated in sulfuric acid in presence of chloride ions, in form of $\mathrm{NaCl}$ $\left(\mathrm{H}_{2} \mathrm{SO}_{4} 1 \mathrm{M}+\mathrm{Cl}^{-} 10^{-3} \mathrm{M}\right)$. Potentiodynamic polarization method is used for inhibitor efficiency testing. The pitting corrosion current shows that increasing concentration of the inhibitor causes a decrease in pitting current density, and inhibition efficiency increases with increasing concentration of the inhibitors.
\end{abstract}

Keywords: amino acid, methionine, potentiodynamic polarization.

\section{Introduction}

The study of steel corrosion phenomena has become an important industrial as well as academic topic [1]. In recent years, a number of eco-friendly corrosion inhibitors have been exploited as green alternative to toxic and hazardous compounds $[2,3]$.

The amino acids which contain carboxyl and amino functionalities bonded to the same carbon atom are non-toxic, relatively cheap and easy to produce in purities greater than $99 \%$. It has been shown by various authors that some amino acids can act as corrosion inhibitors, which has generated an increasing interest in these compounds as substitute to conventional corrosion inhibitors that are usually toxic $[4,5]$. The present work was undertaken to investigate the corrosion inhibition behavior of methionine on mild steel in $1.0 \mathrm{M} \mathrm{H}_{2} \mathrm{SO}_{4}+10^{-3} \mathrm{Cl}^{-}$ solution. The experimental technique used is potentiodynamic polarization.

\section{Experimental}

The samples used in the chemical investigation are with sizes $(D=6 \mathrm{~mm}, \mathrm{~d}=4 \mathrm{~mm})$ and inside a Teflon tube having fixed with epoxy resin as shown in Fig. 1 and the methionine structure in Fig.2.

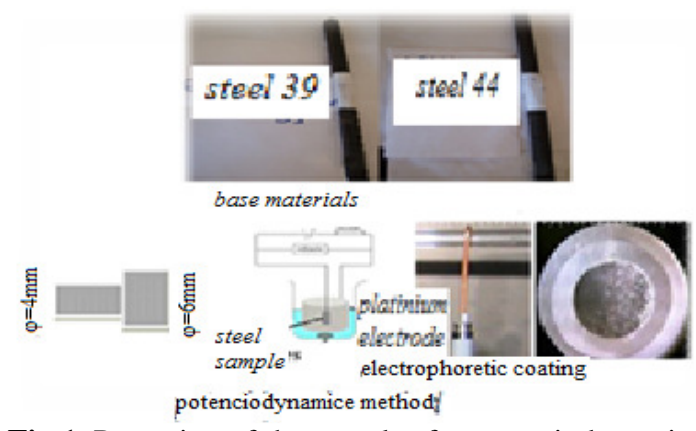

Fig.1. Preparing of the samples for potentiodynamic measurements. 


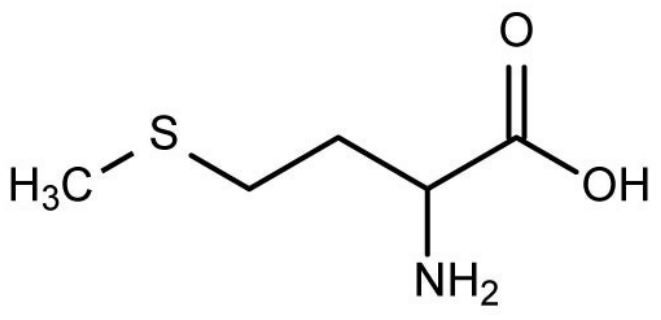

Fig.2. The structure of methionine.

Prior measurement, the steel samples are polished with different emery paper, rinsed with double distilled water and dried in air [6, 7, 8]. Table 1 shows the chemical composition of steel 39 and steel 44 .

Table 1. Composition of low alloy carbon steel tested

\begin{tabular}{|c|c|c|}
\hline $\begin{array}{l}\text { Element } \\
\text { (Mass- } \\
\text { \%) }\end{array}$ & Steel 39 & Steel 44 \\
\hline $\mathbf{C}$ & 0.37 & 0.445 \\
\hline $\mathbf{S i}$ & 0.17 & 0.348 \\
\hline $\mathbf{M n}$ & 0.51 & 0.780 \\
\hline $\mathbf{C r}$ & 0.60 & 0.118 \\
\hline $\mathbf{N i}$ & 0.60 & 0.263 \\
\hline $\mathbf{C u}$ & 0.30 & 0.324 \\
\hline $\mathbf{P}$ & 0.040 & 0.0720 \\
\hline $\mathbf{S}$ & 0.040 & 0.0440 \\
\hline \multicolumn{2}{|c}{} \\
\end{tabular}

The measurements were conducted in $1.0 \mathrm{M}$ sulfuric acid $+10^{-3} \mathrm{Cl}^{-}$solutions at the following methionine corrosion inhibitor concentrations: $0.25 \mathrm{~g} / \mathrm{L}, 0.5 \mathrm{~g} / \mathrm{L}, 0.75 \mathrm{~g} / \mathrm{L}$ and $1 \mathrm{~g} / \mathrm{L}$. All tests were obtained in deaerated solutions.

The concentration range of inhibitor employed was 0.25 to $1 \mathrm{~g} / \mathrm{L}$ as presented in Table 2 .

Electrochemical potentiodynamic measurements were carried out in a three-electrode electrolysis cylindrical tempered glass cell. Steel 39 and steel 44, an $\mathrm{Hg} / \mathrm{HgSO}_{4}$ electrode and platinum electrode were used as working, reference and auxiliary electrodes, respectively.

The polarisation curves were recorded with a Potentiostat/Galvanostat/TACUSSEL PJT 24-2 model at a scan rate of of $3 \times 10^{-2} \mathrm{~V} / \mathrm{min}[7,9]$.
The linear Tafel plots are utilized to provide information about the corrosion rate of mild steel and inhibitor efficiencies in $0.1 \mathrm{M} \mathrm{H}_{2} \mathrm{SO}_{4}+10^{-3} \mathrm{Cl}^{-}$ solutions containing different concentration of methionine.

Table 2. The matrix for potentiodynamic measurements

\begin{tabular}{|c|c|c|c|c|c|}
\hline \multirow{2}{*}{$\begin{array}{c}\text { Test } \\
\text { number }\end{array}$} & \multicolumn{5}{|c|}{ Methionine Concentrations (g/L) } \\
\cline { 2 - 6 } & Blank & 0.25 & 0.5 & 0.75 & 1 \\
\hline 1 & + & & & & \\
\hline 2 & & + & & & \\
\hline 3 & & & + & & \\
\hline 4 & & & & + & \\
\hline 5 & & & & & + \\
\hline
\end{tabular}

Corrosion current density was determined using the cutting point of Tafel extrapolation line and $\mathrm{v}_{\mathrm{corr}}$ was calculated according to Faraday's law [7, 10] (1)

$$
V_{c o r r}=(K * a * i) /(n * D)
$$

where a represents the atomic weight of the metal $(\mathrm{a}=56 \mathrm{~g} / \mathrm{mol}), \mathrm{i}$ - corrosion current density in $\left(\mu \mathrm{A} / \mathrm{cm}^{2}\right), \mathrm{n}-$ the number of electrons exchanged during metal dissolution $(n=2), D$ - the density in $\left(\mathrm{g} / \mathrm{cm}^{3}\right)\left(\mathrm{D}=7.86 \mathrm{~g} / \mathrm{cm}^{3}\right)$ and $\mathrm{K}$ is a constant which equals to 0.00327 if corrosion rate $\left(\mathrm{V}_{\text {corr }}\right)$ is calculated in $[\mathrm{mm} / \mathrm{y}][8]$.

Inhibition efficiency $(I E)$ is calculated by the following formula:

Inhibitor Efficiency $(\%)=[(C R$ uninhibited $-C R$

inhibited)/CR uninhibited] $\times 100$

\section{Results and Discussions}

The potentiodynamic polarization behavior of steel 39 in $1 \mathrm{M} \mathrm{H}_{2} \mathrm{SO}_{4}$ solution with $10^{-3} \mathrm{M}$ chloride ions in the absence and in the presence of different concentrations $0.25 \mathrm{~g} / \mathrm{L}, 0.5 \mathrm{~g} / \mathrm{L}, 0.75 \mathrm{~g} / \mathrm{L}, 1 \mathrm{~g} / \mathrm{L}$ of methionine is shown in Fig. 3.

Figure 4 represents the potentiodynamic polarization curves of steel 44 in $1 \mathrm{M} \mathrm{H}_{2} \mathrm{SO}_{4}$ solution with $10^{-3} \mathrm{M}$ chloride ions in different concentration $0.25 \mathrm{~g} / \mathrm{L}, 0.5 \mathrm{~g} / \mathrm{L}, 0.75 \mathrm{~g} / \mathrm{L}, 1 \mathrm{~g} / \mathrm{L}$ of methionine. 


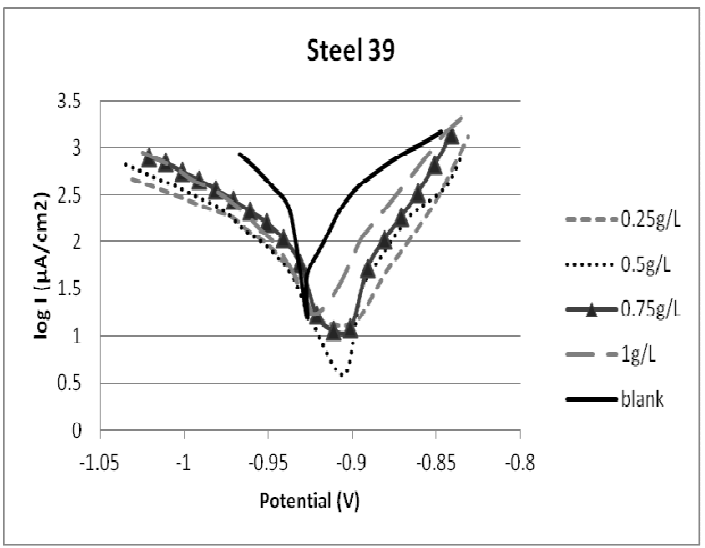

Fig. 3. Potentiodynamic polarization curves for Steel 39 in de-aerated $1 \mathrm{M} \mathrm{H}_{2} \mathrm{SO}_{4}$ solution with $10^{-3} \mathrm{M}$ chloride ions (blank) containing different concentration of methionine.

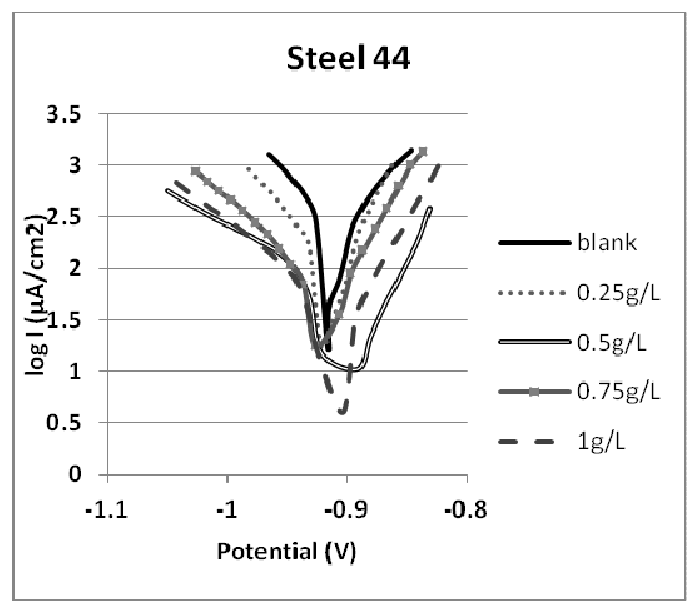

Fig. 4. Potentiodynamic polarization curves for Steel 44 in de-aerated $1 \mathrm{M} \mathrm{H}_{2} \mathrm{SO}_{4}$ solution with $10^{-}$ ${ }^{3} \mathrm{M}$ chloride ions (blank) containing different concentration of methionine.

The corrosion rates $(\mathrm{mm} / \mathrm{year})$ and protection efficiency values using different concentration of methionine are presented in Table 3 .

The inhibition efficiency of our corrosion inhibitor against the corrosion of steel in $1.0 \mathrm{M}$
$\mathrm{H}_{2} \mathrm{SO}_{4}+10^{-3} \mathrm{M} \mathrm{Cl}^{-}$can be explained on the basis of the number of adsorption sites, their charge density, molecular size, mode of interaction with the metal surface and the ability to form a metallic complex. The $\pi$ electrons and free electrons on the $\mathrm{S}$ and $\mathrm{N}$ atoms form bonds with the metal surface [8].

In addition, the corrosion rate decreased with the increasing concentrations of the corrosion inhibitor. This point can be explained by the adsorption of corrosion inhibitor molecules on the sample surface, forming a protective mild steel surface [11].

The presence of the amino acid inhibitor decreases the corrosion rate and increases the inhibition efficiency as shown in Table 3 , due to the adsorption of amino acids on the metal surface.

Table 3. Corrosion rate and protection efficiency for Steel 44 and Steel 39 in de-aerated $1 \mathrm{M} \mathrm{H}_{2} \mathrm{SO}_{4}$ solution with $10^{-3} \mathrm{M}$ chloride ions, with and without inhibitor.

\begin{tabular}{|c|c|c|c|c|}
\hline \multirow{2}{*}{$\begin{array}{c}\text { Conc. } \\
\text { of } \\
\text { methio } \\
\text { nine }\end{array}$} & \multicolumn{4}{|c|}{ Mark of steel material } \\
\cline { 2 - 5 } & $\begin{array}{c}\mathrm{V}_{\text {corr }} \\
\mathrm{mm} / \mathrm{y} \\
\text { ear }\end{array}$ & $\begin{array}{c}\text { Prot.Eff. } \\
\%\end{array}$ & $\begin{array}{c}\mathrm{V}_{\text {corr }} \\
\text { mm/year }\end{array}$ & $\begin{array}{c}\text { Prot.Eff. } \\
\%\end{array}$ \\
\hline Blank & 2.32 & - & 3.31 & - \\
\hline $\begin{array}{c}0.25 \\
\mathrm{~g} / \mathrm{L}\end{array}$ & 0.87 & 62.5 & 1.4 & 57.70 \\
\hline $0.5 \mathrm{~g} / \mathrm{L}$ & 0.84 & 63.79 & 0.89 & 73.11 \\
\hline $\begin{array}{c}0.75 \mathrm{~g} / \\
\mathrm{L}\end{array}$ & 0.77 & 66.81 & 0.83 & 74.92 \\
\hline $1 \mathrm{~g} / \mathrm{L}$ & 0.59 & 74.14 & 0.62 & 81.27 \\
\hline
\end{tabular}

Accordingly, the inhibitors are found to retard the dissolution of the metals and act as mixed-type inhibitors. The presence of $\mathrm{R}-\mathrm{S}-\mathrm{R}$ in molecular structure of methionine provokes an increase of the inhibition efficiency, which can be attributed to the fact that the sulfur containing amino acids can be adsorbed as bidentate ligands in which surface coordination is taking place through both the amino group (or carboxylic group) and the $-\mathrm{S}-$ moiety [12]. 


\section{Conclusions}

From the above study it may be concluded that:

- The methionine act as an efficient corrosion inhibitor on a mild steel surface in $1 \mathrm{M} \mathrm{H}_{2} \mathrm{SO}_{4}$ in presence of $\mathrm{Cl}^{-}$.

- Potentiodynamic polarization methods show that Steel 39 and steel 44 present higher sustainability against corrosion in this aggressive media.

- The presence of the inhibitor (methionine) significantly lowers the corrosion rate.

- Methionine mitigates the corrosion rate of the steel 39 from $2.32 \mathrm{~mm} /$ year to $0.59 \mathrm{~mm} /$ year and for the steel 44 from $3.31 \mathrm{~mm} /$ year to 0.62 $\mathrm{mm} /$ year.

- The inhibition efficiencies of methionine increased with increased of inhibitor concentration.

- Methionine gave $74.14 \%$ and $81.27 \%$ inhibition efficiencies respectively for steel 39 and steel 44.

\section{References}

* E-mail address: janoalbana@yahoo.com

[1]. F. Bentiss, M. Lagrenée and M. Traisnel, Corrosion, 56, 733-742 (2000).

[2]. N.O. Eddy, F.E. Awe, C.E. Gimba, N.O. Ibisi and E.E. Ebenso, Int. J. Electrochem. Sci., 6, 931-957 (2011).
[3]. K.F. Khaled, J. Solid State Electr., 13, 17431756 (2009).

[4]. K.F. Khaled and M.A. Amin, J. Appl. Electrochem., 39, 2553-2568 (2009).

[5]. M. Behpour, S.M. Ghoreishi, M.K. Kashani and N. Soltani, Mater. Corros., 60, 895-898 (2009).

[6]. M. Abdallah, Portugaliae Electrochimica Acta 22, 161-175 (2004).

[7]. M. G. Fontana, Corrosion Engineering, McGraw-Hill (1986).

[8]. A. Jano, A. Lame and E.Kokalari, Ovidus University Annals of Chemistry, accepted for publication, doi: 10.2478/auoc-2014-0002 (2014).

[9]. R. G. Kelly, J. R. Scully, D. W. Shoesmith and R. G. Buchheit, Electrochemical Techniques in Corrosion Science and Engineering, CRC Press (2002).

[10]. E. Bardal, Engineering Materials and Processes, Corrosion and Protection, SpringerVerlag (2004).

[11]. B.M.Mistry, N.S. Patyl, S. Sahoo and S. Junhari, Bull. Mater. Sci., 35, 459-469 (2012).

[12]. M. N. Rahuma, M. B. EL-Sabbah and I. M. Hamad, ISRN Corrosion, Article ID 895120, 7 pages,. doi: 10.1155 /2013/895120 (2013)

Submitted: April 12 2014 Accepted in revised form May $24^{\text {th }} 2014$ 